\title{
Why Indiana Jones is Smarter Than the Post-Processualists*
}

JOHN BINTLIFF

Department of Archaeology, Durham University, UK

Post-Processualism's influence is waning in Britain, linked to the decline of its parent Post-Modernism. Both lost credibility through attempting to dominate discourse, and their negative implications for human rights. Modernism and its offspring Processualism had reflected the scientism and socioeconomic centralism that dominated the 20th century up until the 1970s. Jameson and Harvey have exposed their Post-Modernism as a superficial aesthetic movement spawned by Post-Fordist economics. Perceived from the History of Ideas this temporal succession is the recurrent opposition between Positivist and Idealist philosophies. Wittgenstein's philosophy shows a 'third way' where objective and subjective approaches are complementary tools for scholarship. In Cognitive Processual archaeology a pragmatic merger arises from these formerly competing traditions.

THE DECLINE OF THE

POST-PROCESSUAL AND

POST-MODERN MOVEMENTS

In a review article of the national conference of Theoretical Archaeology in Britain (TAG) (held at Lampeter University in December 1990), I was led to comment (Bintliff 1991) that Post-Processualism was triumphant as the leading discussion topic in British archaeological theory. Just one year later, on the occasion of the next TAG conference (at Leicester University in December 1991), I was to find my evaluation of the situation dramatically changed; reading the auspices from current discussion and publication had led me to consider that the influence of the movement was already declining, and there were abundant reasons to foresee its coming demise, albeit over a period of several years. This paper was pre-

* A paper read at the Theoretical Archaeology Group conference in December 1991, at Leicester University; revised January 1993. sented in substantially its present form at that conference.

The most recent TAG conference, just a few months ago (at Southampton University in December 1992), has confirmed the trend: a much publicized 'Great Debate' between Processualism (Binford, Renfrew) and PostProcessualism (Tilley, Barrett) was almost universally judged a disappointing rerun of an old and tired argument. In the many and varied symposia which constituted the real 'main courses' of the conference, avowedly Post-Processualist contributions were marginalized and unimpressive. In contrast, it was a striking characteristic of many of the most impressive and innovative papers that they adopted an approach dubbed 'Cognitive Processualism' by Renfrew (Renfrew 1981, 1982, cf. Bintliff 1986).

This rapid shift in Post-Processualism's fortunes is a mirror of the crumbling edifice of its intellectual parent Post-Modernism in the Humanities. In both cases, it is paradoxically the success of these movements that has created the mechanism for their de- 
cline. The existence of an established body of books and papers by Post-Modernists and Post-Processualists has allowed scholars, including advocates of the movements themselves, the opportunity for mature reflection on the concepts involved and their potential, if any, for the future development of the relevant disciplines. The judgement is increasingly negative. In every discipline PostModernism is patently under siege, its ideas and practices being systematically taken apart by the growing number of its critics, not least those who some years ago espoused its cause and now condemn its failings.

What should we now seek to salvage from the wreck of Post-Modern archaeology? Until quite recently, I would have wanted to rescue quite a few concepts and approaches from the Post-Processual era (indeed see Bintliff 1991): in the writings of Ian Hodder this would have included the importance he has given to the role of the individual, and the increased awareness he has demanded for the different experiences of ethnic groups and women in the past. In the work of Chris Tilley and Mike Shanks I would have seen a future for their recurrent emphasis on revealing strategies of power and dominance both in past societies and in the organization of modern archaeology.

However, listening to current discussions in other disciplines, a clear picture is emerging of the PM agenda as inimical to the genuine interests of the individual, or to those peripheralized and subordinated sectors of society such as women and ethnic minorities.

\section{CONCEPTUAL CRITIQUES}

First to fall has been the bastion of PostModernist Architecture, indeed it has been convincingly argued that this always existed more on the written page than it ever did in concrete or steel. A tower-block housing a multinational, even if playfully decorated with Post-Modernist references to historical architectural styles, is behind its deceptively ironic facade, still a multinational monolith.
The Post-Modernist guru Derrida has collaborated with an architect (Tschumi at $\mathrm{La}$ Villette), but even those sympathetic to a truly Post-Modern and even Deconstructionist Architecture admit that it is unlikely to be very effective at putting a roof over our heads, not to mention other 'functional' elements such as walls, doors and rooms (Eddy 1990).

As for Literary Studies, from where much of the Post-Modern agenda derives, the chorus of criticism of Post-Modernist readings has become deafening. One striking focus for attack is the self-promoting egotism of Post-Modern critics, who, in following their credo of 'The Death of the Author', set themselves up as more creative and interesting than the writers whose works they are supposedly illuminating. It was symptomatic of the increasing distancing of both writers and critics from the Post-Modernist literary approach that Malcolm Bradbury and David Lodge, significantly both of them fine contemporary creators of literature as well as professional teachers of the subject, recently went on record (The South Bank Show, 1991) as stating that Post-Modernism was a movement inimical to the creation of any new literature.

Let us note, then, that the Post-Modern individual, as in the deconstructionist slogan 'The Death of the Author', suffers loss of autonomy and even total fragmentation as the unwitting instrument of floating discourses. Ethnic groups and women are likewise, in the Post-Modern approach, compartmentalized and effectively peripheralized as 'the other', to be treated as an incommensurate sphere outside of the male sphere of socio-economic power and rationalism; they are discouraged from unified action to assert their rights, as both group solidarity and political action are seen as white, male establishment tendencies.

As for the war on power structures, it has been widely pointed out in every discipline (for Geography, for example, see Curry 1991:223; and for Archaeology see the in- 
vited comments in Shanks, Tilley et al. 1989) that the gurus of Post-Modernism (PM) and indeed Post-Processualism (PP) typically retain all the traits of establishment dominance structures: they accept positions in the academic teaching establishment, adopt traditional modes of talk-down lecturing, cultivate establishment publishers, build up a clientele of postgraduate acolytes (especially relying on the mind-closing strategy of bibliographic exclusion), and using traditional forms of belittling propaganda on behalf of their programme vis-à-vis the preceding establishment agenda, strive with noise and aggression to dominate the minds and bodies of the intellectual sectors of the academic community. It is apposite to quote a review of a collection of PM geographical writings purporting to liberate the discipline from traditional elitist theorists: 'let there be no mistake: this book is for Mandarins, not for Gambian peasants or even run-of-the-mill geographers' (Tuan 1989, quoted in Curry 1991:219). The reader of PP texts will doubtless find a resonance.

If we turn specifically to a consideration of Post-Processualism, the dissolution of the main pillars of that movement is becoming readily apparent. Ian Hodder, happy to associate himself with the whole relativistic ethos of Post-Modernism in his Reading the Past of 1986 (Hodder 1986), now admits that Post-Processualism has only posed critical questions and failed to give answers or alternatives. His own more recent work, for example The Domestication of Europe (Hodder 1990) is Structuralist rather than PostStructuralist, dogmatically readable rather than unprogrammed and rewritable: in essence, it is an exercise in Renfrew's 'Cognitive Archaeology' (1982) that has tacitly dropped the Post-Modern agenda. In a recent lecture (Durham University, November 1990) Hodder significantly referred to the need for 'a modified objectivity', and at the 1992 Southampton TAG he publicly preached the importance of a Processual approach to the past. Even more remarkable was his scathing review of Shanks and Tilley's version of Post-Processualism in the Norwegian Archaeological Review (Hodder 1989). Here he falls out with them on two accounts: first, for advocating what Hodder now feels to be futile, if mainstream PostModern ideas; secondly, for their total inconsistency in promoting at one and the same time, a relativistic approach to an unknowable past and present, and a thoroughly dogmatic, Marxist, prescriptive interpretation to both past and present. Hodder's increasing disillusionment with Post-Modernism and his gradual retreat into Cognitive Processualism, and Shanks and Tilley's confused and inconsistent presentation of a Post-Modern agenda, are revealing of the gradual disintegration of the Post-Processualist enterprise.

Considering the progressive collapse of Post-Modernism, Hodder's pragmatic disengagement is timely if he wishes to preserve his central position in future mainstream archaeological theory. But what are we to make of the jarring contradictions he and most other commentators have found in the work of Shanks and Tilley, between their preaching of the open text of Post-Modernism and a strident Marxist activism? Consider these remarkable statements made by those writers in this journal (NAR 1989): "we [have] abandoned any attempt to create a privileged or foundational discourse' (p. 7) and 'It is important to analyze . . . the mass media, popular and fictional writing about the past, museum presentations, and the rapidly growing heritage industry. It also means intervening in all these sectors, taking power, taking control' (p. 11) (Shanks et al. 1989, my emphases). I can account for the muddle of Shanks and Tilley's philosophy, and in doing so I shall also be indicating what I think is worth saving from the Post-Modern, Post-Processual movement, what their most significant inheritance will be.

\section{THE CONTEXTUAL CRITIQUE}

Ironically (and Post-Modernism's favourite style is irony), we learn most from Post-Mod- 


\begin{tabular}{|c|c|}
\hline Modernism & Post-modernism \\
\hline romanticism/Symbolism & paraphysics/Dadaism \\
\hline form (conjunctive, closed) & antiform (disjunctive, open) \\
\hline purpose & play \\
\hline design & chance \\
\hline hierarchy & anarchy \\
\hline mastery/logos & exhaustion/silence \\
\hline art object/finished work & process/performance/happening \\
\hline distance & participation \\
\hline creation/totalization/synthesis & decreation/deconstruction/antithesis \\
\hline presence & absence \\
\hline centring & dispersal \\
\hline genre/boundary & text/intertext \\
\hline semantics & rhetoric \\
\hline paradigm & syntagm \\
\hline hypotaxis & parataxis \\
\hline metaphor & metonymy \\
\hline selection & combination \\
\hline root/depth & rhizome/surface \\
\hline interpretation/reading & against interpretation/misreading \\
\hline signified & signifier \\
\hline lisible (readerly) & scriptable (writerly) \\
\hline narrative/grande histoire & anti-narrative/petite histoire \\
\hline master code & idiolect \\
\hline symptom & desire \\
\hline type & mutant \\
\hline genital/phallic & polymorphous/androgynous \\
\hline paranoia & schizophrenia \\
\hline origin/cause & difference-difference/trace \\
\hline God the Father & The Holy Ghost \\
\hline metaphysics & irony \\
\hline determinancy & indeterminancy \\
\hline transcendence & immanence \\
\hline
\end{tabular}

Fig. 1. Schematic differences between Modernism and Post-Modernism (from Harvey, 1989, Table 1.1., after Hassan 1985).

ernism by studying the very rise and florescence of the Post-Modern movement itself, if we conduct, as it were, an archaeological investigation into its origins and development. Post-Modern approaches to life, present and past, comprise a set of attributes which can be tabulated in contrast to those typical for the preceding Modernist (cf. in archaeology Processualist) approaches (Fig. 1), bearing in mind that individual Modernist or Post-Modernist writers may only utilize a selection of these concepts and moods. Clearly there is a radical change of stated agenda, supporting the belief of Post-Processualists that their adoption of Post-Modernist perspectives represents a revolutionary shift in ways of talking about human society.
And yet Post-Modernism is a cultural manifestation fixed in time and space, or rathergiven its esoteric and elitist tendencies (essentially being a kind of 'Trivial Pursuit' played mainly in university seminar rooms, and galleries of art and photography) — a subculture. Like any other cultural trend PostModernism is amenable to investigation from the standpoint of its contemporary historical context. The rise of Post-Modernism in the 1980 s is certainly not a chance event, the autonomous discovery of a few clever people locked away from the world, but can be shown to be a manifestation in the cultural sphere of an underlying sea change in the socio-economic conditions of the leading industrial societies, and increasingly of the less developed parts of the world. 
JAMESON: THE INTELLECTUAL MALAISE OF LATE CAPITALISM

If Post-Modernism can be said to have been born with the much-publicized destruction of a modernist housing estate in 1972 (Jencks 1984), the key to its true nature was already exposed in a now classic and perceptive discussion of the emergent phenomenon by Jameson in the New Left Review of 1984 (Jameson 1984).

Jameson drew careful attention to the close and logical relationship between the rise of the cultural aesthetic of Post-Modernism, and the rapid contemporary changes in everyday lived experience as the major industrial societies moved from what has been termed the Fordist form of capitalism into a new era, from the mid-1970s, termed 'postFordist' capitalism. To simplify the contrast, Fordism is typified by centralized, regionally bound, large plant economics, whether in the private or state sector, closely mirrored by centrist, interventionist planning from regional and national state authorities. PostFordism is typified by decentralized, smallerscale production centres, the fragmentation of production, the loss of regional embeddedness, the demolition of central government interventionist programmes of the 'nanny-state' variety. The significance of the mid-1970s for the rapid spread of post-Fordism and its cultural reflector, Post-Modernism, is due to the series of financial crises experienced in all leading capitalist societies in this era, associated with monetary instability, the oil crisis and the development of new capitalist competitors from outside of the Europe-USA economic bloc.

For Jameson, the emergence of PostModernism was effectively a symptom of the experience of societies where traditional certainties of time, place, community, political commitment were being undermined by remote and seemingly incomprehensible forces beyond one's sphere of meaningful engagement. Submissive to this sense of instability and powerlessness, Post-Modernism seeks comfort by moulding itself to the mood of the times, making a virtue out of weakness and disillusionment. If we cannot make contact with the forces that control the world around us, have lost faith in ideologies that promise us that degree of control, and life seems an ever-changing superficial experience, then that 'depthlessness' becomes a philosophy of life, something to give way to. A classic novel, or the results of an excavation, are merely the stage (Tilley 1989), rather than the play, upon which we can each as reader or excavator imagine amusing personal fantasies without the risk of an author or a real lived past imposing constraints by voicing their beliefs and lives at us.

Ian Hodder, without recognizing this contextual grounding to the Post-Modern movement, has nonetheless intelligently seen through the essentially paralyzing nature of its tenets and begun his retreat to realist Cognitive Processualism. Shanks and Tilley, however, unwittingly provide us (Shanks, Tilley et al. 1989) with ideal case-study material for documenting how two socially aware, politically committed, thinking intellectuals of the 70 s and early 80 s, by jumping on the academically chic bandwagon of Post-Modernism, have allowed themselves to become the unthinking mouthpieces of late capitalism and the New Right in the 1990s. The conversion has been only partial, producing that philosophical schizophrenia so typical of their publications.

\section{HARVEY: FLEXIBLE ACCUMULATION AND THE DISSOLUTION OF COMMUNITY}

Jameson's highly influential paper stimulated, and will now certainly be superseded by, a remarkable book published in 1989 from Britain's acknowledged leading theorist in Geography, David Harvey. Entitled The Condition of Postmodernity (Harvey 1989), its very name challenges the high ground of the contemporary era by closely following that of the classic Post-Modernist book by Lyotard-The Postmodern Condition (Lyotard 1984). 
Harvey begins by reminding us of the wellestablished causative relationship that linked the dominance of Modernism and Positivism throughout the first half of this century, with the reality and general ethos of technological and scientific advance, and central largescale planning in both state and business sectors (cf. Bintliff 1986). Building on Jameson's insights, Harvey then proceeds to document in much more detail the historical reasons for the massive redirection of government, commerce and industry during the last 15 years, concentrating on the world economic crises of the $1970 \mathrm{~s}$ and the deliberate decision by leading financial groups to restructure towards what is now being called Flexible Accumulation or post-Fordist economics, a process tied closely to the activities of conservative governments in dismantling statist controls over national and regional capitalism and removing socioeconomic regulation.

Behind the Modernist trend of the period to the 1960s lay an overall growth of productivity for the leading industrial countries; world trade was expanding, a fact which could compensate for internal failings such as the progressive decline of those countries' traditional industries. Corporate wealth enabled employee wealth to rise, and government tax revenue; these surpluses could be deployed to reinforce employee allegiance through bonuses and financial subsidies, or, in the case of the state, to fund state welfarism to succour those excluded from rising incomes. The open alliance of social welfarism and corporate philanthropism was strengthened by the regionalism shared by established businesses and the active contact points of local and central government (for the latter in Britain, local councils, county councils, hospitals and social security offices). This regionalism merged effortlessly into most people's sense of personal rootedness into regional communities. Particularly in the immediate postwar cross-party welfarist initiatives in most capitalist democracies, individual fates were seen as as- sociated in a very positive way with the socioeconomic advancement of the region, the nation and the developed world.

In crystal clear fashion, Harvey shows us how the 1970s crisis of capitalism, where growth or even stability of production and consumption patterns throughout the capitalist world were thrown in the balance, marked a decisive end to these traditional ways of organizing citizens, labour and capital. In the ensuing recession and the increasing threat of total market dominance by more efficient and cheaper products from Eastern Asia, a new mode of economic survival was born, the regime of Flexible Accumulation. Both company and state decks had to be stripped bare for action in what has become an accelerating race to corner ever more insecure and deflating markets or income.

For companies and their diminishing core staff, the regional base is expendable: relocation at short notice, perhaps to a distant country, can dump a local workforce whose existence is tied to that enterprise. For company management every stage of the production and distribution process can be dissociated from a fixed workforce and even a fixed lower management: the trend is toward subcontracting with the most successful bidders and contract employees being taken on for further employment. Ideal employment, overhead, and investment conditions for a company are those where anyone can be dismissed at short notice or moved around the country at will, and where failings at a production or distribution point, not least labour rumblings, no longer impact on company fortunes since these units are replaceable through cancellation of contract. (This is also a good description of the current employment structure of Professional Archaeology in Britain today.) Meanwhile, in the public sphere conservative governments progressively take down those structures of community erected by prosperous welfarism, reducing every possible organ of state to free enterprise. 
Thus, from every direction the individual's identification with communal action and shared achievement is attacked; the infamous injunction by a British right-wing politician to the unemployed to 'get on your bike' situates the individual as an isolated adventurer pursuing self-centred goals, for, as Margaret Thatcher told us, "there is no such thing as society'. The result is, predictably, not a more democratic and more comprehensively affluent society-the rich get richer, and the poor get poorer.

Harvey takes us further, into the totally disorientating effects of the accelerating compression and indeed negation of time and space that has accompanied the shift to postFordist economics: finance no longer sits tied to heavy machines in mills that dominate their dependent community, it flows restlessly around the world in money markets that are open 24 hours a day.

In parallel with the rapacious stripping down of business, the accelerated economic competition set in motion by the 1970 s crises has led to strategies that strive to increase production turnover time and promote consumerism as the centre of individual existence. We are encouraged to live only on the surface, pursuing fashionable extravagances. Only in the privileged circles of secure academic employment and in the few remaining subsidized research studentships could such disturbing, forced realignments of everyday life become a subject for celebration, as it has been in that submissive intellectual pawn of post-Fordist economics-the Post-Modern movement. Post-Modernism is commonly summed up as 'depthlessness', a view of every experience in life as intangible, lacking fixed significance. The Emperor of classic PostModernism has clothes-blurred images and word-games, but simply no body, no concept of common humanity, no moral groundings, no desire to participate in politics, no sense of tradition, purposefulness. As befits a movement divorced from action, it is essentially an aesthetic movement, a mode of expression.

Little wonder then, that a genuinely Post-
Processual archaeology does not recognize a 'real past' (death of the historic actor as well as the author?), decries the search for any kind of coherent social norms in the past, for links that tie people in the past with ourselves, and promotes excavation as theatre (Tilley 1989). We could indeed only expect that Post-Processualism would be characterized by a self-promotion and expressionism in the presence of the past that denies previous societies their genuine voice: attitudes that Post-Modern literary critics are now being so justly ridiculed for.

\section{CONTEXTUALIZING POST-PROCESSUALISM AND PROCESSUALISM IN 20th-CENTURY HISTORY}

Now, if, as we have argued, the Processualism of New Archaeology was in a significant way the unwitting offspring of that centralist, techno-scientific state and commercial power which has dominated the first three generations of this century, and Post-Processualism equally the unconscious creation of the decentralized, flexible accumulation postFordist world economic regime, characteristic of the last 20 years, our first conclusion has to be this:

Behind the claims of Post-Processualism to liberate the individual, the genderdisempowered, the ethnic peripheries, behind the deconstruction of establishment dominance structures-we now see revealed the hidden hand of vast, coldly manipulative structures deployed by a new phase of crisis capitalism. Post-Processualism is symptomatic of the ever-increasing remoteness of the individual from sources of power, rather than the reverse.

Secondly, for those of us concerned with the understanding of long-term historic and prehistoric sequences, the archaeology of the Post-Modern movement teaches us the opposite to its official dogmas: culture is not in the least autonomous and self-creative, the right of every individual historic actor to alter and rewrite; culture, not least Post-Modernist 
and Post-Processualist culture, is intimately bound up with the measurable mass trajectory of conditions of work, class, status, and the control over the forces of production-a materialist interpretation is unavoidable.

Yes-I have clearly nailed my colours to the mast by employing an analytical, singleminded perspective to my theme, revealing myself as an unregenerate positivist. My commitment to a continuation of Processual logic certainly originates in my critical exposure to the New Archaeology movement as both an undergraduate and postgraduate, during the time of its dominance in archaeological theory. In thus favouring Processualism, you might reasonably be encouraged to challenge me with the immortal words of Mandy Rice-Davies: 'He would say that, wouldn't he?'.

If we were to accept the preceding analysis that located Processualism and Post-Processualism as, in essence, epiphenomena towed along by the successive stages of socioeconomic modes of production, who am I to privilege the preceding intellectual movement over the current one? Despite the continual claims by both Modernism and PostModernism to stand aside from the drift of time and explain the nature of life for all eras, it cannot really be denied that they are inexorably tied to specific historic contexts and find their origin, meaning and indeed demise from secular shifts in socio-economic structures. I might seem at risk of ceding the battlefield at the moment of victory, if by relativizing Processualism we opened the way to that total relativistic perspective fundamental to Post-Modernism.

CONTEXTUALIZING

POST-PROCESSUALISM AND

PROCESSUALISM IN THE HISTORY OF IDEAS

My first step to free us from that paradox is to point out that the contrast between analytical, objectivist, positivistic philosophy, and a relativistic, subjective emotionalism is not merely to be found by comparing the earlier part of this century with its final decades, but represents a polarization that has recurred in cyclical form throughout the history of Western philosophy. Nietzsche in the 19 th century famously characterized the two traditions (Nietzsche 1872) as the Apollonian and the Dionysian; in the Arts the earlier part of his century witnessed the supplanting of one by the other in the replacement of Classicism by Romanticism. At the least, therefore, the 20 th century mainstream paradigms represent cyclical viewpoints whose separate appeal has validity for many different eras and societies. This is still compatible with the suggestion that paradigm change is mobilized by non-intellectual changes in socio-economic conditions.

\section{WITTGENSTEIN AND THE 'THIRD WAY'}

A rounded vision of how the Apollonian and Dionysian, Modernist and Post-Modernist approaches can exist in useful complementarity can be found in the mature reflections of Ludwig Wittgenstein (Monk 1990), often viewed as the most influential philosopher of this century. Indeed, consider the paradox that both Modernists and PostModernists claim him as a key figure in their intellectual underpinnings. However, as recent lively discussion of his works reveals, neither tradition does the breadth of his thought full justice, but rather takes selections of his insights to suit their narrower perspectives.

For Wittgenstein, philosophy ended its work in his demonstration that disputes about the absolute 'truth' of propositions were a meaningless exercise. In reality when we use certain concepts we are merely employing valid counters in legitimate moves within specific language games; each sphere of discourse has its own set of terms, and our use of words or concepts in one language game is incommensurate with that appropriate to another. From this position PostModernists claim Wittgenstein as a pioneer 
of a purely relativistic view of concepts, but only by disregarding the crucial commentary by Wittgenstein on language games: terms of discourse are not free-floating mind-worlds disconnected from reality but-Wittgenstein stresses - words have no value at all deprived of action, and social action at that. The meaning of terms is defined, reproduced and redefined purely in the context of group behaviour; it is what people do and say about their doing that defines discourse.

For Wittgenstein the recognizable major discourses in any society are bound to mutual networks of action and behaviour; as we have seen with Modernism and Post-Modernism, the discourses of social planning or of aesthetics likewise operate in the experience of social everyday life. We can therefore discuss the current state of society within the discourse of Feminism, or Marxism, situating the observed social world around us within those terms of debate appropriate to such ideal, morally founded ideological projections; but we can equally well plot the distribution of power, residence and wealth from a modernist pattern-seeking perspective, utilizing dynamic models to account for variability in the data culled eclectically from every conceivable source of theory; the two activities would be equally valid but not commensurate, in Wittgenstein's view; the reality of spatial patterning is a positivistic discourse of one kind, the nature of the ideal society is quite another language game.

Modernism claims less: in the end its essence is a methodology for recognizing and creating order, and this has variously served totalitarian regimes and social welfarism. The Dionysian, Idealist position claims more: it eschews rational analysis in favour of inspiration; it is a discourse of emotional release which has led to a progressive selfawareness of the potential of the individual human spirit, but also, as might be seen in the case of Martin Heidegger, can encourage an obsession with the concept of 'being' that is too easily perverted into fervent support

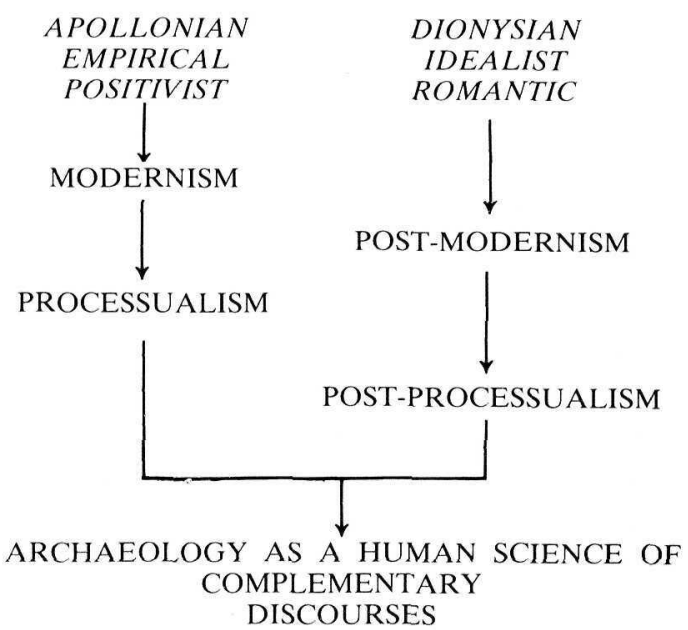

Fig. 2. The future of archaeological theory.

for the aggressive Will, and even into the blood and soil mysticism of the Third Reich.

\section{CONCLUSION}

We can and must complement our discourses, and cannot expect them to displace each other permanently; better to value their different angles of view and the different purposes they serve. What use are wonderful statistical correlations if we cannot use the past to serve the present? On the other hand, what credit can we give to a view of the past which abuses its realities in the cause of blatant political propaganda? The future of archaeological theory (Fig. 2), if hopefully Wittgensteinian in the proper sense of a full understanding of his theories, will acknowledge these complementary spheres of analysis in archaeology, give scope to the recognition of obscure species by a patient palynologist and the disciple of Foucault spiralling into verbal vortices over the odd word in an antique letter to the Society of Antiquaries. This will be Archaeology as a Human Science.

The present paper was presented in essentially its present form at the 1991 TAG conference. Since then, as noted in my introduction, another TAG, in fact a 'EUROTAG' with a record 750 delegates, has 
met at Southampton. The most remarkable feature of this latest conference was the way in which speaker after speaker, British and Continental, displayed a total disregard for affiliation to 'Processualist' or 'Post-Processualist' factions, and deployed an eclectic attitude to the various objectivist and subjectivist approaches debated over in the last 20 years. Yet equally consistently, this merger of formerly oppositional traditions within a new pragmatics of practice, saw the speaker grounding his or her feet on evidence, an archaeological record, testability. The Theoretical Archaeology of the 1990s is undeniably going to be 'Cognitive Processualism' (cf. Renfrew 1981, 1982): in recognizing this, we are also surely seeing the first steps towards a hybrid 'Human Science of Archaeology' as prefigured in the first draft of this paper a year earlier.

\section{THE PHILOSOPHICAL}

\section{SPECULATIONS OF INDIANA JONES}

Now it seems pretty clear to me that the world's most famous archaeologist, Professor Indiana Jones, is a follower of Wittgenstein. Although he has not left us such an impressive philosophical oeuvre as the Cambridge luminary, we do possess a rare statement of Professor Jones's commitment to the key propositions of the Tractatus Logico-Philosophicus and the Philosophical Investigations.

In an admittedly rare classroom scene during that memorable biopic Indiana Jones and the Last Crusade, our hero is seen addressing a large class of adulating students. The theme: nothing less than 'The Nature of Archaeology'. After commenting that the discipline is $95 \%$ library work (an assertion which the rest of the film makes no attempt to support, if we except the scene where Indiana and his attractive assistant are engaged in skullduggery beneath a library floor), Professor Jones throws out a culminatory aphorism: "Archaeology is about Facts; if you want the Truth, go next-door to the Philosophy Department!'
And that's why, gentle reader, Indiana Jones is smarter than the Post-Processualists.

\section{REFERENCES}

Bintliff, J. L. 1986. Archaeology at the interface: an historical perspective. In Bintliff, J. L. \& Gaffney, C. F. (eds.), Archaeology at the Interface, 4-31. BAR Int. Ser. 300, Oxford.

Bintliff, J. L. 1991. Post-modernism, rhetoric and scholasticism at TAG: the current state of British archaeological theory. Antiquity 65, 274-278.

Curry, M. R. 1991. Postmodernism, language, and the strains of Modernism. Annals of the Association of American Geographers 81, 210228.

Eddy, D. H. 1990. Review of Postmodern Sophistications by David Kolb. Times Higher Education Supplement, December 7th, 1990, 21.

Harvey, D. 1989. The Condition of Postmodernity. Basil Blackwell, Oxford.

Hodder, I. 1986. Reading the Past. Cambridge University Press, Cambridge.

Hodder, I. 1989. Comments on archaeology into the 1990s. Norwegian Archaeological Review 22(1), 15-18.

Hodder, I. 1990. The Domestication of Europe. Basil Blackwell, Oxford.

Jameson, F. 1984. Postmodernism, or the cultural logic of late capitalism. New Left Review 146, 53-92.

Jencks, C. 1984. The Language of Post-Modern Architecture. London.

Lyotard, J. 1984. The Postmodern Condition. Manchester University Press, Manchester.

Monk, R. 1990. Ludwig Wittgenstein. Jonathan Cape, London.

Nietsche, F. W. 1872. Die Geburt der Tragödie aus dem Geiste der Musik. Leipzig.

Renfrew, C. 1981. Space, time and man. Transactions of the Institute of British Geographers N.S.6, 258-278.

Renfrew, C. 1982. Towards an Archaeology of Mind. Cambridge University Press, Cambridge.

Shanks, M., Tilley, C. and Invited Comments 1989. Archaeology into the 1990s. Norwegian Archaeological Review 22(1), 1-54.

Tilley, C. 1989. Excavation as theatre. Antiquity 63, 275-280. 